\title{
Principles of genetic predisposition to malignancies
}

\author{
Tadeusz Dębniak, Jan Lubiński \\ International Hereditary Cancer Centre, Department of Genetics and Pathology, Szczecin, Poland
}

Corresponding author: Tadeusz Dębniak, International Hereditary Cancer Centre, Department of Genetics and Pathology, Pomeranian Medical University, Połabska 4,70-115 Szczecin,Poland, e-mail: debniak@wp.pl

It is estimated that around $30 \%$ of all malignancies are caused by a "high-risk" genetic predisposition [1]. This estimation is based on an evaluation of occurrence of disease among monozygotic twins. If one of them is affected with prostate (PC) or breast cancer (BC), then the probability of occurrence of this disease in the second sibling is $40 \%$ for PC and $30 \%$ for BC [2]. The concordance among monozygotic twins is even higher when occurrence of malignancies regardless of the site of origin is taken into consideration (e.g. breast cancer in one individual, stomach cancer in the sibling).

Genetic susceptibility to cancer can be divided into monogenic and polygenic predisposition.

\section{Monogenic predisposition to cancer}

Such diseases are caused by constitutional mutations of single genes, present in all cells of the body. DNA mutations can be detected in all malignancies. In the majority of cases somatic mutations are identified changes which are present in malignant tissue only. To date, among hereditary causes of malignancies, the most frequently diagnosed background detected in routine molecular testing of the patients is monogenic predisposition with autosomal dominant type of inheritance. Each individual has two copies (alleles) of the gene responsible for a particular feature or disease, in the same locus on homologous chromosomes. One copy is inherited from the mother, the second one from the father. According to autosomal dominant type of inheritance the presence of inborn mutation in a single copy of the gene leads to disorder [3]. This is true in the case of proto-oncogenes, e.g. mutations in RET oncogene predispose to MEN2 syndrome. In the majority of cases, malignancies are caused by mutations of the tumour suppressor genes such as $p 53$, or DNA repair genes such as $\mathrm{MSH} 2$, which show a recessive pattern at the molecular level. Carriers of these mutations develop cancer due to somatic inactivation of the second allele (most frequently deletion) during their lifetime [4-8].

Pedigrees of monogenic diseases with autosomal dominant inheritance are characterised by occurrence of the disorder in all generations (vertical transmission), among men and women, among almost $50 \%$ of the relatives $[9,10]$

The pedigree of a family with autosomal dominant disease is presented in Figure 1.

In this particular family cancers occur at a younger age in each subsequent generation (so-called anticipation).

Autosomal dominant inheritance does not show characteristic pedigree features in cases of:

- germline (present in sex cells) mutations arising "de novo" - disease absent among ancestors and siblings of the proband (individuals undergoing genetic counselling); subsequent generations can be affected - Figure 2;

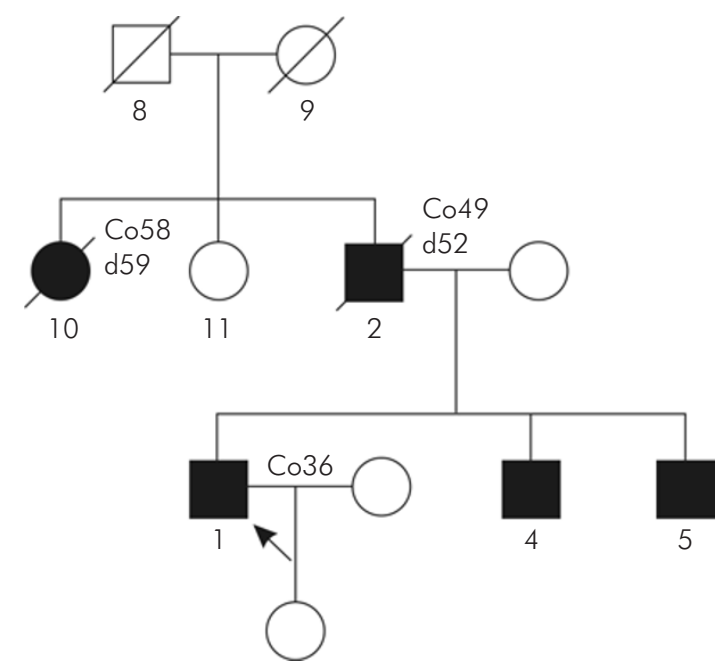

Co36 - colorectal cancer diagnosed at 36 d52 - died at age 52

Figure 1. Family with Lynch syndrome - pedigree features of monogenic autosomal dominant disease 


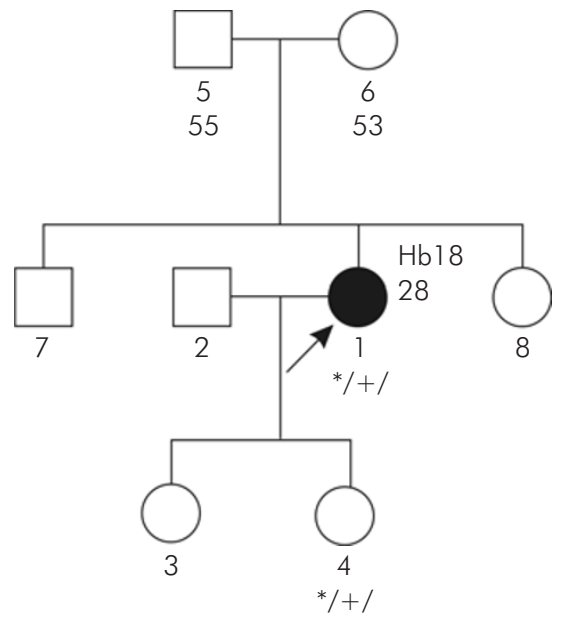

$\mathrm{Hb}$ - haemangioblastoma

*/+/ - individual carrying constitutional mutation

Figure 2. Pedigree of family with disease caused by germline "de novo" mutation within VHL gene

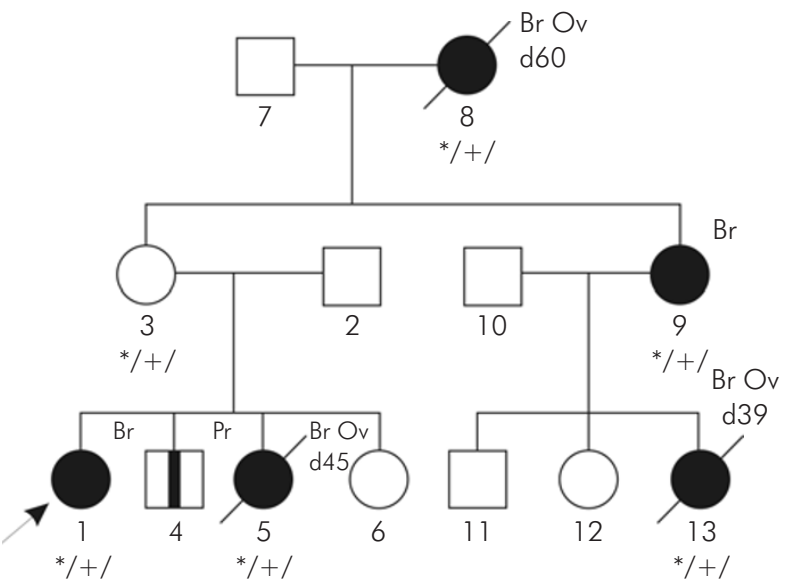

d60 - died at age 60

Ov - ovarian cancer

$\mathrm{Pr}$ - prostate cancer

Figure 4. Phenocopy - breast cancer unrelated to constitutional mutation in family with BRCA1 mutation

- mosaic mutation present only in some of the tissues; such alterations arise in the fetus "de novo" during pregnancy; single individuals in the family are affected; mutation can be inherited only if it is present in sex cells;

- "low penetrance" mutations; penetrance is defined as the proportion of carriers of mutation who develop cancer; in strong cancer familial aggregations it reaches $80-90 \%$, but in cases with

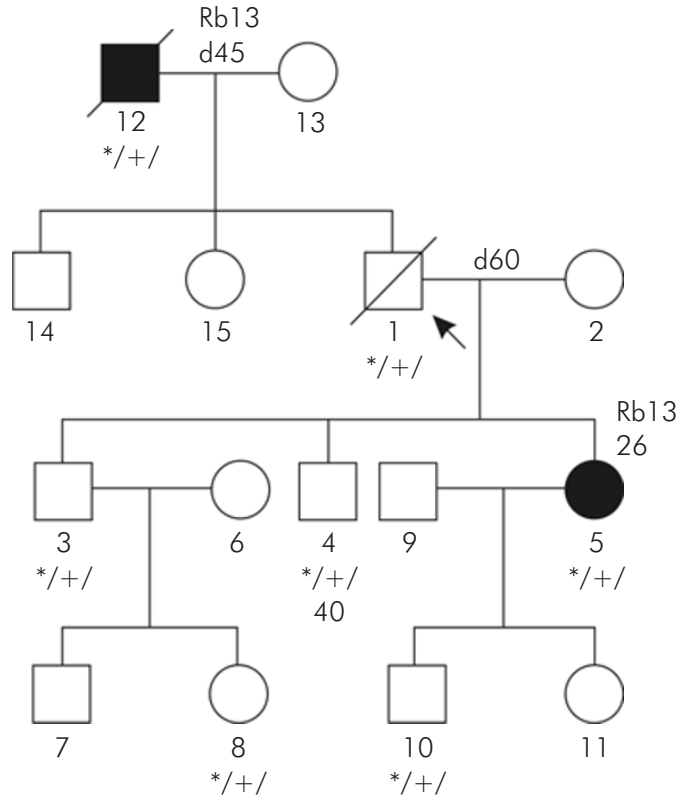

$\mathrm{d} 45$ - died at age 45

$\mathrm{Rb} 13$ - retinoblastoma diagnosed in $3^{\text {rd }}$ year of life

*/+/ - individual carrying constitutional mutation

Figure 3. Pedigree of family with low penetrance $R b 1$ gene mutation

low penetrance mutations it is much lower, and thus single individuals only are affected [1 1-15]; an example is presented in Figure 3;

- mutations predisposing to disease occurring among one gender only, e.g. mutations of the BRCAl gene are detected among both males and females, but only women develop ovarian cancer;

- small families with low numbers of relatives.

Evaluation of the pedigree and clinical data of families with aggregations of cancers should exclude phenocopies (accidental malignancy not related to mutation responsible for the aggregation of malignant tumours) [16-18]. Figure 4 shows an example of a family with 4 breast cancers caused by BRCA 1 mutation and one breast cancer in a woman without BRCA1 mutation.

\section{Polygenic predisposition to cancer}

In polygenic type of inheritance single individuals are usually affected.

As the results of the studies performed in our centre panels of DNA mutations/polymorphisms, which increase the risk of malignancies, were identified in over $90 \%$ of unselected breast cancers $196 \%$ of cases with BC diagnosed over $50,99 \%$ of lobular cancer cases Tables 1-3), $89 \%$ of colorectal cancers, $72 \%$ of 
Table 1. Frequency of identified panel of markers in unselected breast cancers and controls [9]

\begin{tabular}{lcc}
\hline Gene/Marker & Cancer & Controls \\
\hline BRCA1 & $2.7 \%(26 / 977)$ & $0 \%(0 / 977)$ \\
\hline CHEK2 & $11.9 \%(113 / 951)$ & $6 \%(59 / 977)$ \\
\hline p53 & $10.1 \%(85 / 838)$ & $5.7 \%(52 / 918)$ \\
\hline TNR & $55.6 \%(419 / 753)$ & $45.8 \%(397 / 866)$ \\
\hline FGFR - GG & $18.3 \%(61 / 334)$ & $13.9 \%(65 / 469)$ \\
\hline CDKN2A & $7 \%(19 / 273)$ & $5.4 \%(22 / 404)$ \\
\hline XPD - GG & $41 \%(104 / 254)$ & $36.4 \%(139 / 382)$ \\
\hline XPD - CC/AA & $17.3 \%(26 / 150)$ & $14 \%(34 / 243)$ \\
\hline BRCA2 & $7.3 \%(9 / 124)$ & $4.8 \%(10 / 209)$ \\
\hline XPD - AA & $20 \%(23 / 115)$ & $18.6 \%(37 / 199)$ \\
\hline Any marker & $90.6 \%(885 / 977)$ & $83.4 \%(815 / 977)$ \\
\hline Statistic & & $P=3 \times 10-6$ \\
\hline
\end{tabular}

Table 3. Frequency of identified panel of markers in all breast cancers diagnosed at age above 50 and controls [9]

\begin{tabular}{lcc}
\hline Gene/Marker & Cancer & Controls \\
\hline BRCA1 & $2.1 \%(14 / 667)$ & $0 \%(0 / 667)$ \\
\hline CHEK2 & $11 \%(72 / 653)$ & $4.8 \%(32 / 667)$ \\
\hline p53 & $11 \%(64 / 581)$ & $5.4 \%(34 / 635)$ \\
\hline TNR & $55.9 \%(289 / 517)$ & $45.3 \%(272 / 601)$ \\
\hline FGFR - nAA & $68.9 \%(157 / 228)$ & $60.8 \%(200 / 329)$ \\
\hline BRCA2 & $5.6 \%(4 / 71)$ & $2.3 \%(3 / 129)$ \\
\hline XPD - CC/AA & $13.4 \%(9 / 67)$ & $6.3 \%(8 / 126)$ \\
\hline NOD2 & $13.8 \%(8 / 58)$ & $6.8 \%(8 / 118)$ \\
\hline XPD - GG & $48 \%(24 / 50)$ & $35.5 \%(39 / 110)$ \\
\hline Any marker & $96.1 \%(641 / 667)$ & $89.4 \%(596 / 667)$ \\
\hline Statistic & P =2.4 × 10-6 \\
\hline
\end{tabular}

malignant melanomas, $36 \%$ of ovarian and $27.5 \%$ of prostate cancers [19]. DNA alterations associated with "moderate" risk may have a significant clinical impact.

Associations of "moderate risk" mutations and polymorphisms of many genes and additional influence of environmental factors can significantly increase the risk of cancer development in individuals carrying these alterations. Accumulation (linear association) of the
Table 2. Frequency of identified panel of markers in lobular carcinoma and controls [9]

\begin{tabular}{lcc}
\hline Gene/Marker & Cancer & Controls \\
\hline BRCA1 & $0.7 \%(1 / 140)$ & $0 \%(0 / 140)$ \\
\hline CHEK2 & $19.4 \%(27 / 139)$ & $4.3 \%(6 / 140)$ \\
\hline$p 53$ & $10.7 \%(12 / 112)$ & $6 \%(8 / 134)$ \\
\hline BRCA2 & $9 \%(9 / 100)$ & $4.8 \%(9 / 126)$ \\
\hline FGFR - nAA & $75.8 \%(69 / 91)$ & $60 \%(72 / 120)$ \\
\hline TNR & $72.7 \%(16 / 22)$ & $39.6 \%(19 / 48)$ \\
\hline NOD2 & $16.7 \%(1 / 6)$ & $0 \%(0 / 29)$ \\
\hline M3K - nAA & $80 \%(4 / 5)$ & $41.4 \%(12 / 29)$ \\
\hline Any marker & $99.30 \%(139 / 140)$ & $87.90 \%(123 / 140)$ \\
\hline Statistic & \multicolumn{2}{c}{$P=0.00073$} \\
\hline
\end{tabular}

DNA alterations can be identified when the total risk of cancer is the sum of risks of single DNA alterations, e.g. total risk of cancer development increased twofold in compound carriers of two mutations in genes $A$ and $B$ (both mutations associated with 50\% increased cancer risk). In other cases a non-linear association (interaction) can be diagnosed (e.g. total risk increased fivefold in compound carriers of the previously mentioned mutations of genes A and B [20]).

\section{References}

1. Lynch HT, Fusaro RM, Lynch J. Hereditary cancer in adults. Cancer Detect Prev 1995; 19: 219-233.

2. Lichtenstein $P$, De Faire $U$, Floderus $B$, Svartengren M, Svedberg $P$, Pedersen NL. The Swedish Twin Registry: a unique resource for clinical, epidemiological and genetic studies. J Intern Med 2002; 252: 184-205.

3. Knudson A. Mutation and cancer: a statistical study of retinoblastoma. Proc Natl Acad Sci USA 1971; 68: 820-823.

4. Friedman JM. Genetics and epidemiology, congenital anomalies and cancer. Am J Hum Genet 1997; 60: 469-473.

5. Marra G, Boland CR. Hereditary nonpolyposis colorectal cancer: the syndrome, the genes, and historical perspectives. J Natl Cancer Inst 1995; 87: 1114-1125.

6. Lubiński J, et al. Hereditary tumors - prophylactics, early diagnosis, treatment. Biotechnologia 1996; 35: 202-207.

7. Friedman JM, Dill FJ, Hayden MR, Mc Gillyvary BC. Genetyka, Limon J. (I ed.). Elsevier Urban \& Partner, Wrocław 2000.

8. Lubiński J, Korzeń M, Górski B, Cybulski C, Dębniak T, Jakubowska A, Jaworska K, Wokołorczyk D, Mędrek K, Matyjasik J, Huzarski T, Byrski T, Gronwald J, Masojć B, Lener M, Szymańska A, Szymańska-Pasternak J, Serrano-Fernàndez P, Piegat A, Uciński R, Domagała P, Domagała W, Chosia M, Kładny J, Górecka B, Narod S, Scott R. Genetic contribution to all cancers: the first 
demonstration using the model of breast cancers from Poland stratified by age at diagnosis and tumour pathology. Breast Cancer Res Treat 2008 Apr 15 [Epub ahead of print].

9. Pavlovic-Calic N, Muminhodzic K, Zildzic M, Smajic M, Gegic A Alibegovic E, Salkic N, Jovanovic P, Basic M, Iljazovic S. Genetics, clinical manifestations and management of FAP and HNPCC. Med Arh 2007; 61: 256-259.

10. Petersen GM, Brensinger JD, Johnson KA, Giardiello FM. Genetic testing and counseling for hereditary forms of colorectal cancer. Cancer 1999; 86 (1 1 Suppl): 2540-2550

11. Gryfe R, Swallow C, Bapat B, Redston M, Gallinger S, Couture J. Molecular biology of colorectal cancer. Curr Probl Cancer 1997; 21: 233-300

12. Daley D, Lewis S, Platzer P, MacMillen M, Willis J, Elston RC, Markowitz SD, Wiesner GL. Identification of susceptibility genes for cancer in a genome-wide scan: results from the colon neoplasia sibling study. Am J Hum Genet 2008; 82: 723-736.

13. Rowan E, Poll A, Narod SA. A prospective study of breast cancer risk in relatives of BRCA1/BRCA2 mutation carriers. J Med Genet 2007; 44: e89.

14. Gorski B, Menkiszak J, Gronwald J, Lubinski J, Narod SA. A protein truncating BRCA1 allele with a low penetrance of breast cancer. J Med Genet 2004; 41 : e130.

15. Debniak T, Scott RJ, Górski B, Cybulski C, van de Wetering T, Serrano-Fernandez P, Huzarski T, Byrski T, Nagay L, Debniak B, Kowalska E, Jakubowska A, Gronwald J, Wokolorczyk D, Maleszka R, Kładny J, Lubinski J. Common variants of DNA repair genes and malignant melanoma. Eur J Cancer 2008; 44: 110-114.

16. Friedrichsen DM, Malone KE, Doody DR, Daling JR, Ostrander EA. Frequency of CHEK2 mutations in a population based, casecontrol study of breast cancer in young women. Breast Cancer Res 2004; 6: R629-R635.

17. Humar B, Guilford P. Hereditary diffuse gastric cancer and lost cell polarity: a short path to cancer. Future Oncol 2008; 4: 229 . 239.

18. Sasieni P. Phenocopies in families seen by cancer geneticists. J Med Genet 2007; 44: e82.

19. Gronwald J, Cybulski C, Lubinski J, Narod SA. Phenocopies in breast cancer 1 (BRCA1) families: implications for genetic counselling. J Med Genet 2007; 44: e76.

20. Cybulski C, Gliniewicz B, Sikorski A, Kładny J, Huzarski T, Gronwald J, Byrski T, Debniak T, Gorski B, Jakubowska A, Wokolorczyk D, Narod SA, Lubinski J. Cancer Epidemiol Biomarkers Prev 2007; 16: 572-576. 